\title{
KAJIAN TERHADAP FASAD MALL DI SEMARANG
}

\author{
Aulusia Ika Kosanti, Agung Dwiyanto*).... \\ *) Corresponding author email : agungdwiyanto@arsitektur.undip.ac.id
}

Departemen Arsitektur, Fakultas Teknik, Universitas Diponegoro

\author{
Article info \\ MODUL vol 18 no 2, issues period 2018 \\ Doi $\quad: 10.14710 / \mathrm{mdl} .18 .2 .2018 .101-107$ \\ Received : 26 Nov 2018 \\ Revised : 26 Nov 2018 \\ Accepted : 26 Nov 2018
}

\begin{abstract}
Kota merupakan salah satu tempat kehidupan manusia yang dapat dikatakan paling kompleks, karena perkembangannya dipengaruhi oleh aktivitas pengguna perkotaan. Kota Semarang yang mempunyai fungsi dan peran sebagai Ibu Kota Provinsi Jawa Tengah, menunjukan adanya pertumbuhan fisik yang dilaksanakan oleh berbagai pihak dengan kepentingannya masing-masing. Pembangunan fisik tersebut yang dilaksanakan adalah penyediaan fasilitas perdagangan dan jasa yang didalamnya termasuk bangunan komersial seperti mall. Keberadaan mall yang semakin marak, secara tidak langsung akan meningkatkan persaingan antara mall yang satu dengan mall yang lainnya. Kemampuan untuk menarik konsumen juga sangat perlu dimiliki oleh sebuah mall agar dapat terus mempertahankan keberadaannya salah satunya dengan cara pengaplikasian desain fasad yang menarik dalam perancangan sebuah mall. Keberagaman bentuk fasad bangunan mall berhubungan dengan kualitas visual estetika yang terbentuk dalam setiap bangunan mall yang ada di Semarang. Untuk mengetahui hubungan tersebut, dibutuhkan persepsi pengunjung untuk menilai, sehingga hasil yang didapatkan obyektif.
\end{abstract}

Keywords: Mall; Fasad; Persepsi Pengunjung

\section{PENDAHULUAN}

\section{Latar Belakang Penelitian}

Bangunan komersial di Kota Semarang dapat dikatakan berkembang sangat pesat. Sebut saja mall. Semarang sendiri memiliki lebih dari satu bangunan Aulusia Ika Kosanti, Agung Dwiyanto mall di kotanya. dengan keberadaan mall yang semakin marak, secara tidak langsung akan meningkatkan persaingan antara mall yang satu dengan mall yang lainnya.

Kemampuan untuk menarik konsumen juga sangat perlu dimiliki oleh sebuah mall agar dapat terus mempertahankan keberadaannya. Dalam perancangan sebuah mall, bentuk dan fasad memiliki peranan sangat penting. Fasade atau bagian tampak bangunan adalah unsur yang tidak dapat dihilangkan dari suatu produk desain arsitektur dan bahkan merupakan bagian terpenting dari suatu karya arsitektur, karena elemen tampak inilah yang diapresiasi atau dilihat pertama kali. Melalui fasad kita bisa mendapat gambaran tentang fungsi-fungsi bangunan, selain itu fasad juga berfungsi sebagai alat perekam sejarah peradaban manusia. Dengan mengamati dan mempelajari desain fasad dan kondisi sosial budaya, kehidupan spiritual, bahkan keadaan ekonomi dan politik pada masa tertentu. Karakteristik yang muncul dari desain bentuk dan fasad sebuah bangunan akan membentuk persepsi terhadap pengunjung. (Sinarwastu, 2016)

Keberadaan beragam bentukan fasad bangunan (bangunan komersial) berhubungan dengan kualitas visual estetika yang terbentuk dalam setiap bangunan mall yang ada di Semarang. Untuk mengetahui hubungan tersebut, dibutuhkan persepsi masyarakat untuk menilai, sehingga hasil yang didapatkan obyektif.

Dalam penelitian ini, penulis mengambil 5 sample mall di Semarang yang akan dijadikan sebagai obyek penelitian kemudian dilakukan pengambilan kuisioner oleh responden sebagai data dari penelitian ini. Dari data tersebut akan diketahui fasad mall yang menarik dan tidak atau kurang menarik menurut responden.

\section{TINJAUAN PUSTAKA \\ Pengertian Mall}

Mall merupakan sebuah nama yang sudah tidak asing lagi didengar oleh setiap orang. Pada dasarnya mall merupakan pusat perbelanjaan, hanya saja 
masyarakat sekarang menyebut pusat perbelanjaan sebegai mall. Mall itu sendiri memiliki banyak pengertian.

Berdasarkan (Maitland, 1987) yang dikutip oleh (Sinarwastu, 2016), mall merupakan pusat perbelanjaan yang berintikan satu dan beberapa department store besar sebagai daya tarik retail-retail kecil dan rumah makan dengan tipologi bangunan seperti toko yang menghadap ke koridor utama mall atau pedestrian yang merupakan unsur utama dari sebuah mall dengan fungsi sebagai sirkulasi dan sebagai ruang komunal bagi terselenggaranya interaksi antar pengunjung dan pedagang.

Berdasarkan (Rubenstein, 1978) yang dikutip oleh (Hernandez, 2015), mall diartikan sebagai suatu area pergerakan (linier) pada suatu area pusat bisnis kota(central city business area) yang lebih diorientasikan bagi pejalan kaki. Berbentuk pedestrian dengan kombinasi plaza dan ruang-ruang interaksional.

Berdasarkan (Beddington, Design for Shopping Centre) yang dikutip oleh (Hernandez, 2015), mall merupakan suatu wadah dalam masyarakat yang menghidupkan kota atau lingkungan setempat. Selain berfungsi sebagai tempat untuk kegiatan berbelanja atau transaksi jual beli, juga berfungsi sebagai tempat untuk berkumpul atau berekreasi.

Jadi berdasarkan beberapa definisi tersebut dapat diambil kesimpulan bahwa mall secara arsitektural merupakan suatu ruang rekreasi dan pusat perbelanjaan yang terdiri dari kompleks pertokoan dimana terjadi kegiatan jual beli maupun pertukaran barang dan jasa serta sebagai tempat berkumpul dan berekreasi.

\section{Pengertian Fasad}

Mendengar istilah fasad, banyak orang akan selalu menghubungkannya dengan sebuah bangunan. Menurut (Sastra, 2013), dalam bidang arsitektur facad berarti sebuah wajah bangunan atau bagian muka atau depan suatu bangunan. Fasad merupakan bagian yang sangat penting dari sebuah karya arsitektur, karena elemen ini merupakan bagian yang selalu pertama kali diapresiasi oleh publik ( penikmat karya arsitektur ).

Menurut (Utami, dkk, 2013) yang dikutip oleh (Alfian, 2017) fasad atau bagian tampak bangunan adalah unsur yang tidak dapat dihilangkan dari suatu produk desain arsitektur dan bahkan merupakan bagian terpenting dari suatu karya arsitektur, karena elemen tampak inilah yang diapresiasi atau dilihat pertama kali. Melalui fasad kita bisa mendapat gambaran tentang fungsi-fungsi bangunan, selain itu fasad juga berfungsi sebagai alat perekam sejarah peradaban manusia.

Dengan mengamati dan mempelajari desain fasad dan kondisi sosial budaya, kehidupan spiritual, bahkan keadaan ekonomi dan politik pada masa tertentu.

\section{Unsur-Unsur yang Diamati Pada Fasad}

Dalam arsitektur sendiri, fasad bangunan sering kali adalah suatu hal yang paling penting dari sudut pandang desain, karena ia memberikan suasana bagi bagian-bagian bangunan lainnya. Dari fasad bangunan akan tercipta sebuah karakter visual yang menjadi identitas suatu bangunan itu sendiri.

Hal-hal yang dapat diamati pada fasad bangunan sebagai pembentuk karakter visual yang baik, yaitu :

a. Entrance (pintu masuk)

Pintu masuk menjadi tanda transisi dari bagian publik (eksterior) ke bagian privat (interior). Pintu masuk adalah elemen pernyataan diri dari penghuni bangunan. Posisi entrance pun dapat memberi pengaruh terhadap tampilan fasad.

b. Bukaan

Elemen bukaan dapat menjadi hal yang menarik untuk sebuah fasad bangunan. Elemen bukaan ruang bisa berupa pintu, jendela, BV, dan elemen bukaan estetika.

c. Tanda-Tanda (Sign) dan Ornament

Tanda-tanda (signs) adalah segala sesuatu yang dipasang oleh pemilik toko, perusahaan, kantor, bank, restoran dan lain-lain pada tampak muka bangunannya, dapat berupa papan informasi, iklan dan reklame. Tanda-tanda ini dapat dibuat menyatu dengan bangunan, dapat juga dibuat terpisah dari bangunan.Tanda pada bangunan berupa papan informasi, iklan atau reklame merupakan hal yang penting untuk semua jenis bangunan fungsi komersial. Karena tanda-tanda tersebut merupakan bentuk komunikasi visual perusahaan kepada masyarakat (publik) yang menginformasikan maksud yang ingin disampaikan oleh perusahaan komersial.

d. Geometri

Geometri pada fasad yaitu gagasan formatif dalam arsitektur yang mewujudkan prinsip-prinsip geometri pada bidang maupun benda suatu lingkungan binaan, segi tiga, lingkaran, segi empat beserta varianvariannya seperti bentuk-bentuk yang tidak beraturan. Menurut (Ching, Architecture : Form, Space, \& Order Third Edition, 2008) bentuk-bentuk tidak beraturan merupakan bentuk yang bagian-bagiannya secara alamiah tidak sama dan terkait satu sama lain dengan tidak konsisten. Mereka umumnya asimetris dan lebih dinamis dibandingkan dengan bentuk beraturan. Mereka dapat berbentuk dari bentukbentuk beraturan yang elemen-elemen yang tak beraturannya dikurangkan atau dihasilkan dari suatu komposisi tidak beraturan dari bentuk-bentuknya yang beraturan.

Pengaruh geometri ini dapat dijadikan sebagai artikulasi fasad sebagai point of interest pada bangunan sehingga dapat menciptakan kesan menarik. 


\section{e. Simetri}

Simetri yaitu gagasan formatif yang mengarahkan desain bangunan melalui keseimbangan. Untuk membangun suatu keseimbangan komposisi, simetri harus jauh lebih dominan dari asimetri. Fasad harus memiliki "wajah-wajah" yang mencerminkan solusi terencananya yang berbeda tetapi tetap simetris di dalam diri mereka sendiri.

f. Irama

Irama adalah tipologi gambaran yang menunjukan komponen bangunan dalam bentuk repetasi baik dalam skala besar maupun skala kecil. Komponen yang dimaksud dapat berupa kolom, pintu, jendela atau ornamen. Semakin sedikit ukuran skala yang berulang, dikategorikan ritme monoton, semakin banyak dikategorikan dinamis. (Frie, 2013).

g. Skala dan Proporsi

Skala dalam arsitektur menunjukkan perbandingan antara elemen bangunan atau ruang dengan suatu elemen tertentu dengan ukurannya bagi manusia. Pada konteks fasade bangunan, skala merupakan proporsi yang dipakai untuk menetapkan ukuran dan dimensi-dimensi dari elemen fasade. (Frie, 2013).

Sedangkan proporsi yaitu perbandingan antara satu bagian dengan bagian lainnya pada salah satu elemen fasad. Dalam menentukan proporsi bangunan biasanya mempertimbangkan batasan-batasan yang diterapkan pada bentuk, sifat alami bahan, fungsi struktur atau oleh proses produksi. Penentuan proporsi bentuk dan ruang bangunan sepenuhnya merupakan keputusan perancang yang memiliki kemampuan untuk mengolah bentuk-bentk arsitektur, mengembangkan bentuk-bentuk geometri dasar dan sebagainya, yang tentunya keputusan dalam penentuan proporsi tersebut ada dasarnya. (Frie, 2013).

h. Warna

Teknik pengolahan warna. Warna merupakan salah satu elemen yang sangat berperan untuk menciptakan kesan dan persepsi lagi pengamat (orang yang melihatnya). Warna yang harmonis pada fasade bisa dicptakan dengan cara menonjolkan padu padan warna - warna yang saling bersebelahan atau berdekatan, sebagai contoh misalnya perpaduan antara warna merah, orange, dan kuning atau perpaduan antara warna merah, biru, kuning, dan biru. Padu padan warna yang harmonis secara visual pada fasade bisa terlihat dengan baik karena perpaduan warna saling berdekatan memilki unsur warna yang terdapat pada warna disekitarnya. Agar desain fasade terlihat lebih estetis tambahkan aksentuasi warna, misalnya berilah warna putih diantara paduan warna - warna yang menyala tersebut.

i. Material
Pengaplikasian material pada sebuah tampilan fasad bangunan dapat menjadi suatu artikulasi fasad sebagai point of interest sehingga terlihat menarik. Aplikasi material fasad yang dominan misalnya jika dominan kaca atau kayu akan berkesan hangat dan akrab. Material kaca merupakan elemen yang pada umumnya mendominasi pada fasade bangunanbangunan komersil dan bangunan publik lainnya. Kaca menghadirkan fungsi sebagai jembatan visual antara ruang luar dan dalam bangunan. Hal ini akan lebih mengundang orang yang melalui bangunan untuk lebih tertarik melihat isi dalam bangunan sebelum memutuskan untuk mendatangi/memasukinya.

j. Pengaplikasian Papan

Iklan/Reklame Pengaplikasian papan iklan/reklame dapat dikatakan ideal menurut (Wartina, 2015), jika :

$\square$ Mampu merefleksikan karakter visual kawasan.

$\square$ Mampu menjamin kemampuan pandangan / memiliki sudut pandang untuk dapat dilihat secara jelas.

$\square$ Bentuk yang ada sesuai dengan arsitektur bangunan di mana signage ditempatkan.

$\square$ Merupakan elemen yang menyatu dengan bangunan bukan elemen tambahan.

$\square$ Mampu menyatukan komunikasi langsung atau tidak langsung.

k. Tone (Vocal Point)

Tone (Vocal Point, point of interest, eye catching) menurut (Putra, 2017) memiliki pengertian sesuatu yang dianggap menarik dan mencuri perhatian pengamat dari unsur-unsur yang terdapat didalamnya, yang terlibat dalam vocal point biasanya adalah :

1. Nada (Gelap terangnya warna/gradasi)

Penggunaan nada warna dalam bangunan sangatlah penting apalagi jika bangunan tersebut memiliki fungsi sebagai tempat rekreasi, warna dalam bangunan tersebut harus bersifat menghibur, membuat bahagia, melupakan kepenatan,dll.

2. Tekstur

Tekstur adalah kasar halusnya suatu permukaan bidang. Tekstur dalam suatu bangunan yaitu ada :

$\square$ Tekstur halus

$\square$ Teksturkasar

\section{PEMBAHASAN}

\section{Bentuk Massa Bangunan}

Bentuk massa bangunan merupakan unsur yang paling menarik dari sebuah tampilan fasad bangunan, sebanyak 71 responden memilih bentuk massa bangunan. Bentuk massa bangunan yang menarik untuk fasad bangunan berdasarkan jawaban responden yaitu bentuk massa bangunan yang 
modern, atraktif, dinamis, elegan, mewah, unik, memiliki estetika yang dapat ditonjolkan.

Untuk mengetahui bentuk massa yang menarik dan kurang/tidak menarik berdasarkan responden, maka dilakukan sebuah perbandingan antara Mall 1 yang memiliki perolehan jumlah responden paling banyak dengan Mall yang memiliki perolehan jumlah responden paling sedikit.

\section{Mall 1}

Berdasarkan jawaban responden, bangunan paragon mall dinyatakan memiliki bentuk massa bangunan yang menarik karena dianggap bentuk bangunan yang dimiliki oleh mall 1 atraktif dan dinamis. Menurut Menurut (Ching, Architecture : Form, Space, \& Order Third Edition, 2008) sifat dinamis dapat timbul dari akibat bentuk-bentuk yang tidak beraturan.

Selain itu responden beranggapan bahwa bentuk massa bangunan mall 1 modern, mewahm elegan, unik, serta memiliki nilai estetika tersendiri yang menonjol dibandingkan bangunan lainnya.

\section{Mall 4}

Berdasarkan jumlah jawaban respoden, bentuk massa bangunan Mall 4 memperoleh hasil paling sedikit yang dipilih oleh responden sebagai unsur yang menarik pada tampilan fasad bangunan. Alasan responden menyatakan bahwa bentuk massa bangunan Mall ini aneh dan tidak sesuai dikarenakan bentuk dari atap pada bangunan ini yang berbentuk kubah.

\section{Warna Bangunan}

Unsur yang dapat dikategorikan sebagai unsur yang menarik berdasarkan persepsi responden adalah warna bangunan, sebanyak 57 responden memilih warna sebagai unsur yang menarik pada tampilan fasad bangunan. Untuk warna bangunan yang menarik berdasarkan jawaban responden yaitu warna bangunan yang tidak monoton, terdiri atas lebih dari 1 warna, dan memiliki warna yang cerah Untuk mengetahui warna bangunan yang menarik dan kurang/tidak menarik berdasarkan responden, maka dilakukan sebuah perbandingan antara Mall 5 yang memiliki perolehan jumlah responden paling banyak dengan Mall 3 yang memiliki perolehan jumlah responden paling sedikit.

\section{Mall 5}

Berdasarkan jawaban responden, unsur warna merupakan unsur yang menarik untuk tampilan fasad bangunan. Responden beranggapan bahwa warna pada bangunan mall ini tidak monoton, tidak menggunakan 1 warna saja, dan penggunaan warna merah yang cerah yang dianggap menajadi hal yang menarik untuk bangunan ini. Seperti yang dikatakan oleh (Nugraha, 2016), warna merah memiliki menaklukkan, ekspansif (meluas), dominan (berkuasa), aktif dan vital (hidup). Warna merah juga termasuk dalam golongan warnawarna panas menurut (Monica, 2011).

\section{Mall 3}

Berdasarkan jumlah responden yang ada pada table, diketahui bahwa warna Mall ini dianggap kurang menarik. Responden mengganggap bahwa warna dinding mall monoton, hanya 1 warna, serta warna yang digunakan dianggap terlalu pudar tidak cerah. Menurut (Monica, 2011), warna pada bangunan mall ini termasuk dalam golongan monokromatik sehingga tidak memiliki sifat cerah dan terang pada warna ini.

\section{Ciri Khas/Eye Cathing}

Memiliki ciri khas atau eye cathing pada bangunan berada pada posisi ke 3, dinyatakan sebanyak 26 responden. Untuk mengetahui ciri khas yang menarik dan kurang/tidak menarik berdasarkan responden, maka dilakukan sebuah perbandingan antara Mall 1 yang memiliki perolehan jumlah responden paling banyak dengan Mall 2 dan Mall 3 yang memiliki perolehan jumlah responden paling sedikit.

\section{Mall 1}

Berdasarkan table diatas, Mall ini dinyatakan sebagai bangunan yang memiliki ciri khas berdasarkan pilihan responden. Responden berpendapat bahwa bentuk tampilan dinding fasad bangunan mall ini dinamis dan atraktif yang tidak dimiliki oleh bangunan lainnya. Selain itu responden berpendapat bahwa tekstur dari bangunan ini termasuk dalam kategori tekstur kasar sehingga dapat menampilkan kesan kokoh yang dapat dijadikan sebagai vocal point/eye catching, seperti yang dikatakan pula oleh (Putra, 2017) bahwa tekstur kasar pada fasad bangunan biasanya ada di bagian depan bangunan, tujuannya untuk membuat bangunan ini terlihat kokoh.

\section{Mall 2 dan Mall 3}

Berdasarkan data pada table, Mall 2 dan Mall 3 dianggap kurang atau tidak memiliki ciri khas pada bangunannya oleh sebagian besar responden. Menurut responden, bentuk serta tekstur kedua mall tersebut simple dan biasa saja, sehingga bagi responden kedua tampilan fasad mall tersebut dapat dikatakan tidak menarik.

\section{Material}

Unsur material berada posisi ke 4 dalam urutan unsur yang menarik, dinyatakan sebanyak 19 responden. Untuk material dan tekstur berdasarkan jawaban responden yaitu material dan tektur yang cocok dan sesuai dengan fungsi bangunan serta sesuai dengan konsep bangunan. Untuk mengetahui material bangunan yang menarik dan kurang/tidak menarik berdasarkan responden, maka dilakukan sebuah perbandingan antara Mall 1 yang memiliki perolehan jumlah responden paling banyak dengan Mall 4 yang memiliki perolehan jumlah responden paling sedikit.

\section{Mall 1}


Berdasarkan table sebelumnya, material bangunan pada mall ini dipilih responden sebagai yang paling menarik dibandingkan material pada bangunan Mall 4 . Pengaplikasian material kaca yang diterapkan pada bangunan ini menjadi alasan mengapa responden mimilih material bangunan ini dianggap menarik, meskipun pengaplikasian material kaca tersebut tidak pada keseluruhan bangunan. Dari pengaplikasian material kaca pada dinding fasad bangunan ini, bagi responden dapat menambah kesan modern. Seperti yang dikatakan oleh (Alfari, 2017) bahwa material kaca memberikan kesan modern.

\section{Mall 4}

Berdasarkan table, material bangunan mall 4 dinyatakan sebagai unsur yang dipilih paling sedikit oleh responden. Hal tersebut terjadi karena pendapat responden yang menyatakan bahwa material yang diaplikasikan pada fasad bangunan ini biasa saja, tidak modern karena tidak dijumpai material kaca yang terpasang pada fasad mall ini.

\section{Entrance}

Unsur entrance dinyatakan oleh 18 responden. Untuk entrance berdasarkan jawaban responden yaitu entrance yang jelas, tidak membingungkan, dapat langsung diketahui dan dilihat pengunjung saat datang mengunjungi mall tersebut sehingga pengunjung tidak kesulitan mencari atau menemukan entrance pada bangunan mall. Untuk mengetahui entrance yang menarik dan kurang/tidak menarik berdasarkan responden, maka dilakukan sebuah perbandingan antara Mall 1, Mall 2, Mall 3, Mall 5 yang memiliki perolehan jumlah responden paling banyak dengan Mall 4 yang memiliki perolehan jumlah responden paling sedikit.

\section{Mall 1, Mall 2, Mall 3, Mall 5}

Berdasarkan table, pada keempat mall diatas dipilih responden memiliki entrance yang dapat menarik pengunjung. Menurut (Faroga, 2014) letak entrance harus mewakili pencapaian yang dapat menjangkau segala aktivitas dalam bangunan. Berdasarkan jawaban responden, keempat mall di atas sudah memiliki entrance yang cukup jelas dan dapat dijangkau dengan mudah sehingga pengunjung tidak kesulitan menemukan entrance pada bangunan tersebut.

\section{Mall 4}

Berdasarkan table, entrance mall ini menjadi unsur paling sedikit dipilih responden sebagai unsur yang menarik. al tersebut dikarenakan menurut pendapat responden entrance pada mall memiliki peletakan yang kurang jelas, sehingga pengunjung kesulitan menemukan main entrance pada bangunan ini. Ditambah lagi tidak adanya sebuah petunjuk yang menunjukan sebuah entrance pada bangunan ini, sedangkan menurut Willems dan Ransch (1969) yang dikutip oleh (Faroga, 2014) mengatakan bahwa penggunaan tanda(signage) sebagai pengarah diperlukan pada entrance untuk menggiring pendatang.

\section{Ornament dan Sign/Tulisan Nama Mall}

Ornament dan sign/tulisan nama mall, kedua unsur tersebut berada di posisi ke 6 dan dinyatakan oleh 12 responden. Untuk ornament yang menarik berdasarkan jawaban responden yaitu penggunaan ornament yang sesuai, tidak berlebihan dan tidak kekurangan, sehingga lebih enak dan nyaman dilihat. Sedangkan untuk sign/tulisan nama mall berdasarkan jawaban responden, sign/tulisan nama mall yang menarik yaitu tidak mengganggu tampilan dinding fasad bangunan mall, ukuran tulisan tidak terlalu besar dan tidak terlalu kecil sehingga dapat tetap terlihat enak dan nyaman dilihat dari dekat maupun jauh. Untuk mengetahui ornament yang menarik dan kurang/tidak menarik berdasarkan responden, maka dilakukan sebuah perbandingan antara Mall 2 yang memiliki perolehan jumlah responden paling banyak dengan Mall 3 yang memiliki perolehan jumlah responden paling sedikit.

\section{Mall 2}

Berdasarkan table, mall 2 dipilih oleh responden sebagai mall yang memiliki ornament pada fasad bangunan yang menarik. Ornament yang diletakkan pada sekitar jendela di dinding fasad bangunan dianggap oleh responden sesuai tidak berlebihan.

\section{Mall 3}

Berdasarkan table, Mall 3 dipilih oleh responden sebagai mall yang tidak/kurang menerapkan ornament pada fasad bangunannya, sehingga terlihat biasa saja. Untuk mengetahui sign/tulisan nama bangunan yang menarik dan kurang/tidak menarik berdasarkan responden, maka dilakukan sebuah perbandingan antara Mall 1, Mall 2, Mall 3, Mall 5 yang memiliki perolehan jumlah responden paling banyak dengan Mall 4 yang memiliki perolehan jumlah responden paling sedikit.

\section{Mall 1, Mall 2, Mall 3, Mall 5}

Berdasarkan table, keempat mall diatas dianggap responden memiliki unsur sign/tulisan nama mall yang dapat menarik pengunjung karena, sign/tulisan nama mall pada keempat mall tersebut jelas dan sesuai, tidak terlalu besar maupun terlalu kecil.Peletakaan sign/nama mall juga dirasa sesuai dan jelas.

\section{Mall 4}

Berdasarkan table sign/tulisan nama mall Mall ini dianggap kurang menarik berdasarkan jawaban responden. Hal tersebut dikarenakan sign/tulisan nama pada mall ini tidak jelas peletakknya.

\section{Pola dan Irama}

Unsur pola dan irama dinyatakan oleh 8 responden. Untuk pola dan irama yang menarik berdasarkan jawaban responden yaitu yang memiliki kesamaan atau keselarasan dalam segi bentuk massa bangunannya. 
Untuk mengetahui pola dan irama yang menarik dan kurang/tidak menarik berdasarkan responden, maka dilakukan sebuah perbandingan antara Mall 1 yang memiliki perolehan jumlah responden paling banyak dengan Mall 3 yang memiliki perolehan jumlah responden paling sedikit.

\section{Mall 1}

Berdasarkan pada table, pola dan irama pada bangunan mall 1 dipilih responden sebagai unsur yang menarik karena memiliki kesamaan atau keselarasan (pengulangan) dalam segi bentuk massa bangunannya yaitu bentuk dinding fasad yang runcing, namun pengulangan memiliki skala atau ukuran yang berbeda sehingga memiliki kesan dinamis seperti yang dikatakan oleh (Frie, 2013) semakin sedikit ukuran skala yang berulang, dikategorikan ritme monoton, semakin banyak dikategorikan dinamis.

\section{Mall 3}

Berdasarkan table, pola dan irama pada bangunan Mall ini berdasarkan pendapat responden tidak/kurang menarik karena pengulangan bentuk dan warna yang ada pada fasad bangunan ini terbilang monoton.

\section{Pengaplikasian Papan Iklan/Reklame}

Dan yang terakhir adalah unsur pengaplikasian papan iklan/reklame yang paling sedikit dinyatakan menarik oleh responden, sebanyak 3 responden saja yang menyatakan unsur pengaplikasian papan iklan/reklame menarik. Pengaplikasian papan iklan/reklame, berdasarkan jawaban responden pengaplikasian papan iklan/reklame dapat menarik jika pengaplikasiannya sesuai, tidak menghalangi tampilan dinding fasad bangunan mall. Untuk mengetahui pengaplikasian papan iklan yang menarik dan kurang/tidak menarik berdasarkan responden, maka dilakukan sebuah perbandingan antara Mall 1, Mall 2, Mall 5 yang memiliki perolehan jumlah responden paling banyak dengan Mall 3 dan Mall 4 yang memiliki perolehan jumlah responden paling sedikit.

\section{Mall 1, Mall 2, dan Mall 5}

Berdasarkan jawaban responden, ketiga mall di atas unsur pengaplikasian iklan/reklame dianggap cukup menarik dikarenakan pengaplikasian iklan/reklame pada dinding fasad bangunan tidak menggangu atau menghalangi tampilan fasad bangunan mall tersebut
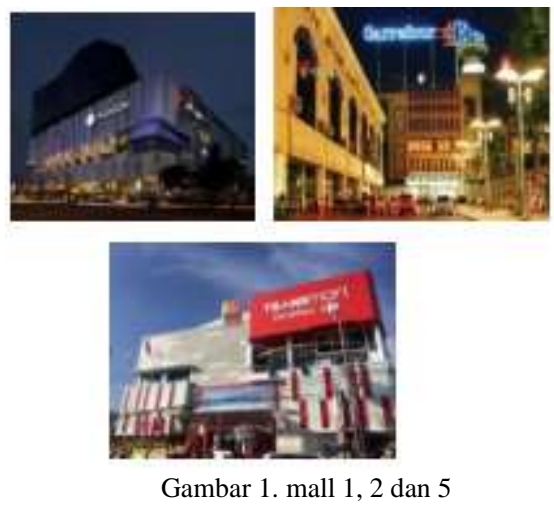

Pengapliksian reklame/papan iklan memiliki dimensi yang sesuai sehingga tetap terlihat jelas di kejauhan, seperti yang dikatakan oleh (Wartina, 2015) bahwa pengaplikasian reklame/papan iklan yang ideal adalah yang mampu menjamin kemampuan pandangan / memiliki sudut pandang untuk dapat dilihat secara jelas. Mall 3 dan Mall 4

Berdasarkan jawaban responden, untuk pengaplikasian papan iklan/reklame pada tampilan fasad bangunan ini dianggap kurang menarik, hal tersebut dikarenakan papan iklan/reklame yang digunakan menghalangi dan menggangu tampilan dinding fasad bangunan mall.

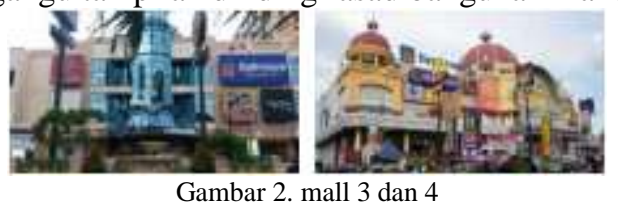

\section{KESIMPULAN}

Dari data dan analisis yang telah didapat dan diolah maka dapat disimpulkan bahwa:

Penilaian persepsi pengunjung mengenai tampilan fasad mall di Semarang yang menarik hingga yang tidak/kurang dilihat dari unsur :

1. Bentuk massa bangunan

2. Warna

3. Memiliki ciri khas/eye cathing pada bangunan mall

4. Material

5. Entrance

6. Ornament

7. Sign/tulisan nama mall

8. Pola dan irama

9. Pengaplikasian papan iklan/ reklame

\section{DAFTAR PUSTAKA}

Alfari, S. (2017). Kaca Sebagai Bahan Bangunan. Retrieved from Kaca Sebagai Bahan Bangunan: https://www.arsitag.com/article/kaca-sebagaibahan-bangunan

Alfian, R. (2017). Persepsi pengunjung terhadap fasad mall gandaria city. Retrieved from persepsi pengunjung terhadap fasad mall gandaria city: 
http://www.academia.edu/30039176/persepsi_pe ngunjung_terhadap_fasad_mall_gandaria_city

Anggara, H. (1988, Desember 30). Entrance dan sirkulasi kendaraan pada bangunan perkantoran di sudirman central bussiness district (scbd). Retrieved from entrance dan sirkulasi kendaraan pada bangunan perkantoran di sudirman central bussiness district (scbd): http://library.gunadarma.ac.id/repository/view/36 3432/entrancedan-sirkulasi-kendaraanpadabangunan-perkantoran-disudirman-centralbussinessdistrict-scbd.html/

Ching, F. D. (2008). Architecture : Form, Space, \& Order Third Edition. Jakarta: Erlangga. Ching, F. D. (2008). Arsitektur: Bentuk, Ruang, dan Tatanan . Jakarta: Erlangga.

Edmondson, G. (2017, May). Outdoor Decorative Screens. Retrieved from Spectrum Custom Designs:

http://www.spectrumdesigns.com.au/portfolioitem/outdoordecorative-screens/

Faroga, R. (2014). Perletakan dan bentuk desain main entrance pada bangunan mall terbuka. Retrieved from perletakan dan bentuk desain main entrance pada bangunan mall terbuka: https://media.neliti.com/media/publications/1839 60-IDperletakan-dan-bentuk-desainmainentran.pdf

Frie, J. (2013, September). Komposisi Pada Fasade Bangunan. Retrieved from Jendela Arsitektur Desain: http://jendelaarsitekturdesain.blogspot.co.id/2013/09/komposis i-pada-fasadebangunan.html

Hernandez, T. (2015, Oktober). Pengertian / Definisi Mall Menurut Beberapa Ahli. Retrieved from Pengertian / Definisi Mall Menurut Beberapa Ahli:

http://www.arsigraf.com/2015/10/pengertiandefinisi-mallmenurut.html

Hidayat, d. (2012). Kajian Bentuk Fasad Depan Hotel Aston Primera. Retrieved from Kajian Bentuk Fasad Depan Hotel Aston Primera: http://download.portalgaruda.org/article.php?arti cle $=57436 \& \mathrm{val}=4292$

Johanis, A. (2015). Perancangan desain sign system pasar rasamala semarang. Jurnal desain komunikasi visual, 3 .

Krier, R. (2001). Architectural Composition, Rob Krier. Jakarta: Erlangga.

Marsella, N. (2017). Penerapan estetika bentuk pada fasade bangunan sebagai landmark kebayoran baru. Penerapan estetika bentuk pada fasade bangunan sebagai landmark kebayoran baru, 6 .

Monica. (2011, Oktober 2). Efek warna dalam dunia desain dan periklanan. Retrieved from efek warna dalam dunia desain dan periklanan: http://researchdashboard.binus.ac.id/uploads/pap er/document/publication/Proceeding/Humaniora/ Vol.\%202\%20No.\%202\%20Oktober\%202011/17 _DKV\%20\%20Monica\%20\%20Laura\%20Christi na.pdf

Nugraha, H. (2016, Maret 19). Teori warna. Retrieved from teori warna: http://nugrahaheru.com/teoriwarna/

Putra, H. E. (2017). Materi Estetika. Retrieved from Materi Estetik: http://www.academia.edu/17266863/Materi_ester ikanya

Sastra, M. S. (2013). Inspirasi Fasade Rumah Tinggal. Yogyakarta: CV. Andi Offset.

Sinarwastu, E. (2016). Tinjauan Umum Shopping Mall. Retrieved from Tinjauan Umum Shopping Mall: http://ejournal.uajy.ac.id/9075/3/2TA13109.pdf

Steven Richard Kamurahan,dkk. (2014). Studi persepsi masyarakat terhadap estetika desain. Retrieved from studi persepsi masyarakat terhadap estetika desain:

https://ejournal.unsrat.ac.id/index.php/jmm/articl e/viewFile/5584/5123

Susiyo, G. (2013, September 15). Sign System. Retrieved from Sign System: http://syirastudio.blogspot.co.id/2013/09/signsystem-2.html

Tye, T. (2016, Februari 24). M Mall O2O. Retrieved from $M \quad$ Mall $\quad \mathrm{O} 2 \mathrm{O}$ : http://www.penangtraveltips.com/m-mallo2o.htm

Wartina, I. (2015). Kajian Terhadap Penempatan Papan Reklame Untuk Menjaga Kualitas Visual Kawasan Komersial Dan Kawasan Konservasi (Jalan Hamka, jalan By Pass Indarung, jalan Pondok dan jalan Niaga - Padang). Kajian terhadap penempatan papan reklame untuk menjaga kualitas visual kawasan komersial dan kawasan konservasi, 5. 